Wojciech Augustyniak "Privatization of Airports as a Way for Air Infrastructure Development", Journal of International Studies, Vol. 3, No 1, 2010, pp. 36-44.

\title{
Privatization of Airports as a Way for Air Infrastructure Development
}

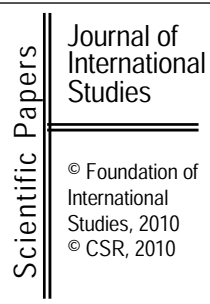

Mgr Wojciech Augustyniak

Poznań University of Economics

w.angustyniak@ue.poznan.pl

\begin{abstract}
The aim of this article is to analyze the trends in ownership structure and business model of European airports. The analysis covers the 10 biggest airports in Poland in a historical depiction as a consequence of deregulation and liberalization of aviation sector. Additionally the article presents an operational depiction as one of the restructuring forms which aims at transferring the financial costs and risk connected with the extension of airport infrastructure to private sector.
\end{abstract} 1st revision: May, 2010 Accepted: June, 2010

Keywords: Polish airports, airport privatization, deregulation.

JEL classification: L93, D53, P2.

\section{Airport privatization}

The term privatization defines the process of moving the function and responsibility completely or partly from the public to private sector. Privatization in a broad sense involves sale or lease of public assets. As far as the airports are concerned, privatization may involve the lease of air and commercial infrastructure to private companies in order to further development [Wells, Young, 2004; p. 32]. The term of airport privatization connects also with the phenomena of commercialization and corporatization.

Commercialization can be interpreted in two ways. According to a law act from 30th August 1996 concerning commercialization and privatization in Poland, commercialization is the first stage of privatization of state-owned companies . It consists in transformation of a state-owned company into a single-person corporation of the Treasury in a form of company with limited liability or public limited company. In this sense the term commercialization is used interchangeably with the term corporatization. In this article the notion of corporatization will concern this term indeed.

The other meaning of the term commercialization is a change in the orientation of actions of state-owned companies from public to commercial aims. The aims involve, among other things, maximization of income and profits from the use of assets, minimization of costs and orientation for the sale of company's products and services [Silverleaf, Turgel, 1994; p. 4]. In this article the notion of commercialization will concern this term indeed.

\section{The specificity of airports}

Airports are the main component of the air transport. They provide the basic infrastructure which enables not only passengers and goods to change from the land transport 
to the air one, but also airlines to take off, land and to attend the air fleet. The basic components of airport infrastructure are runways, taxiways, apron, passenger and cargo terminals. In order to fulfill its function airports have to provide a wide range of services concerning the operation of the air transport. These are, among others, air-traffic control, security of facilities, fire brigade, customer and cargo service. Currently airports can offer as well a wide range of commercial services such as shops, restaurants, hotels but also conference rooms and business parks.

Apart from being a linking between customers and providers of air transport services, airports are also a key element in the development of a region which they are operating. Airports are accelerators of local economy. Due to the multiplier effect they contribute to dynamic economic development of cities and regions (the direct, indirect, induced and stimulated influence). In many countries airports are the integral element of public transport owing to direct connections with railways, highways and local public transport. On the one hand airports are the source of noise and pollution of the environment. On the other hand they are regional economy accelerators providing job posts and increasing the quality if life (especially societies isolated due to geographical reasons).

The owner and the entity managing the airport in order to succeed has to, above all, take into consideration not only the business of customers and air transport services providers but also local communities matters. One of the main factors influencing the effectiveness of airport management and meeting the need of customers, apart from management structure and style, is a form of property, the level of autonomy and the way of financing. The airport operator usually does not provide all the services connected with operating, but it commissions them to external units. The way the operator chooses its subcontractor and factors influencing the negotiations are crucial for further economical effectiveness and relations with customers [Graham 2008; p 2].

\section{Privatization in the historical depiction as a result of corporatization and commercialization}

Airports from the very beginning were the fundamental part of a national and military air system. The development of passenger airports in Europe and Poland had diversified pace. The majority of airports had similar background consisting of military field airports. After The WW II airports were transferred step by step to state authorities and their infrastructure was enlarged for the purpose of the civil use. Nevertheless the entrenched idea was the one about airports treated as the goods of public use than competitive companies. In this situation operational activity is becoming the decisive factor of airports activity, fading financial results into the background.

The next stage of airports development is gaining gradual independence of government. Corporatization of airports and diversification of property into state entities on local, regional and state levels is put into practice in many cases. This procedure ensures taking into consideration local and state business in the process of making strategic decisions. Gradually airports stop being considered as providers of transport infrastructure. What is more governments of other countries start noticing the commercial potential of air sector. Liberalization of regulations and the process of partial or full privatization are used more and more often. These kind of procedures make it possible for airports to be more independent and have bigger possibilities within operational and commercial activity. This is also a direction that encourages companies of private sector to invest and cooperate. 


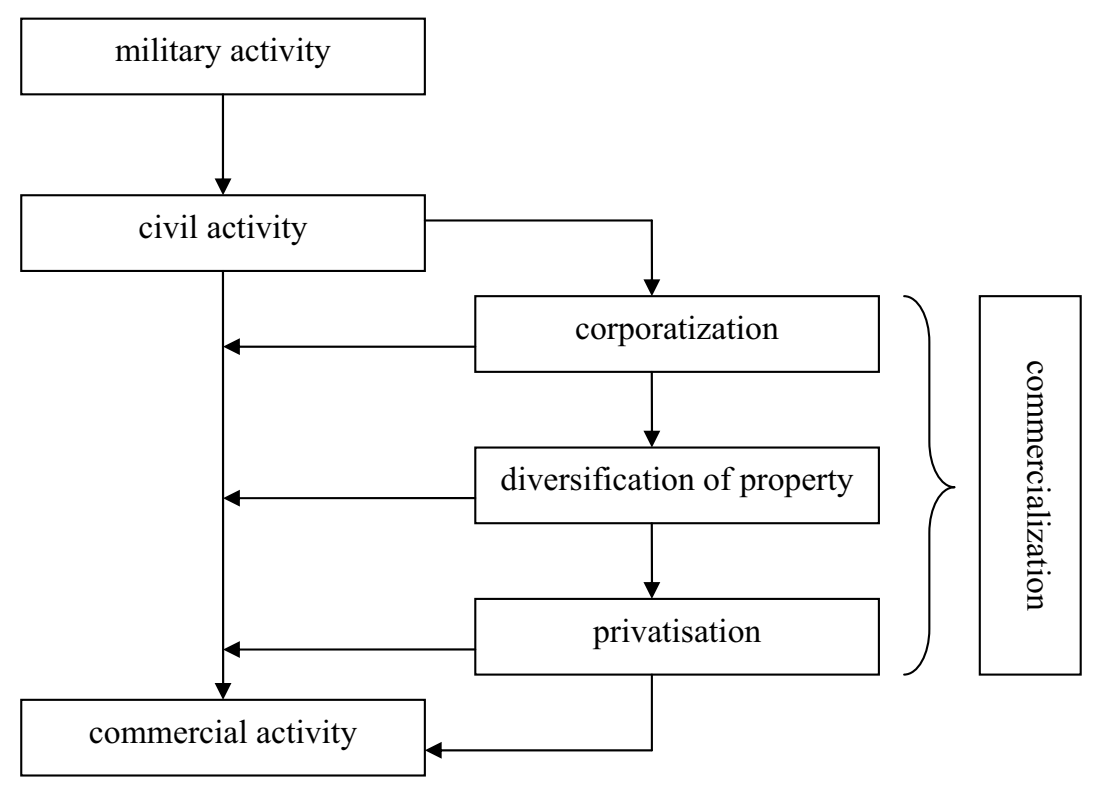

Diagram 1. Evolution o airports' activities

Source: own compilation

Nowadays private companies have increasing influence on functioning of state airports. Many services such as trade, cleaning, security and tickets sale are provided by the private sector. Currently it is estimated that approximately $90 \%$ of people hired in state airports in the USA are employees of private companies.

\section{The aims of privatization}

The most important reasons for airports privatization:

- effectiveness and economic reasons:

o bigger operational effectiveness (in particular the service of firms unconnected with aerial business)

o the possibility of gaining capital from external sources for infrastructure investments

o reliving the state budget of costs for airports development

- generating income for the state budget in recognition of sale or lease of airports assets

o the transfer of risk (among others the decreasing risk of building so called "white elephants")

- social reasons:

O focusing on client - better service standards

$\circ$ maintaining the existing posts and creating new ones

O the increasing of life standards in society

- ideological reasons:

○ political popularity 
- limiting the role of state in economic life in favour of private companies

- strategic reasons:

o the creating of a system that enables airports development which, in turn, facilitates the economic development of a region

At the beginning the privatization of airports was increasing mainly due to desire of disposing strain on state budget. Expenses were connected with subsidizing airports operational services and investments in their development (longer runways, more terminals) as well as environmental factors (pollution, noise) and higher level of security [Forsyth, Gillen, Knorr, Mayer, Niemeier, Starkie, 2004; p. 83]. Traditional airports had to compete for financing with other areas of social services such as health service, education or national defense. The increasing costs connected with airports operating led to the decision of many countries to hand over the management in air sector to private companies with commercial and not public priorities.

One of main arguments standing behind the privatization is the thesis about private companies being more successful in managing corporation assets and assuring high standards of customer service. Freathy supports this theory [Freathy 2004; p.191-193] and he proves that private companies not only seek for the sources of financing investments efficiently but also they are more profit oriented. Due to this fact they have bigger motivation for more effective cost management and searching for new income sources like outside aerial business (advertisements, parking lots, shops, hotels). Advani [Advani, 1999; p.1-2] on his turn, proves that in research concerning service satisfaction airports that are fully or partially owned by private sector and those which are only managed by private companies, are better marked than those operated by state entities. Parker [1999; p.133-46], Vogel [2006; p.197-213] and Vasigh and Haririan [2003] arrived at similar conclusions. There are however many thesis in which privatization has no significant influence on effectiveness e.g. Martin and Roman [2001], Müller, Ülkü and Živanović [2009].

The last but not least argument in favour of airports privatization is the transfer if risk. The risk is connected with, among other, the changing of surrounding, aging of technologies, the possibilities of failure but also the building of so called "white elephants". These are expensive investments which have no economic justification and which the cost of creating and maintenance several times exceeds the income generated (e.g. big terminals aspiring for being the monuments of architecture). In the case of partnership in management of private property the risk of building infrastructure can be shifted from taxpayers to private capital. Privatization increases the probability that strategic decisions will be made on the economic and not political basis [Poole, 1994; p. 8-9].

\section{The attractiveness of the sector}

Nowadays only about $2 \%$ of airports in the world is managed by private companies. Nevertheless the effects gained by the investors so far encourage more and more enterprises to enter the market. The most crucial factors determining the attractiveness of the sector are [Frost, Sullivan, 2006; p 1-3]:

- highly increasing number of passengers and cargo transport in the past few years and similar tendencies in the future

- proceeding increase of the marginal income value and the presence of the scale economy

- enormous but still not exploited enough the commercial potential of airports and neighbouring area 
- significant barriers of entering the market enabling already existing airports the maximalization of income

- the reduced risk of currency fluctuation (the sector is dominated by dollar and euro).

\section{Investors requirements}

The aims of state and potential investors can vary as far as privatization is concerned. In many cases conflict of interests may occur on the field of obligations and benefits. A rapid development and the increase in attractiveness of air sector are not sufficient for investors to recognize a given project as an attractive one. The most significant factors influencing the investors' decisions about putting in a bid are:

- a predicted relation of income and costs

- a relation of limits in investments and predicted increase in air traffic

A relation of predicted income to costs is an amount which enables to answer the question whether an investor with an attained income will be able to cover current expenses and pay possible licensing charges. The limits in investments and predictions concerning an increase in air traffic enable to estimate the time of expenditure return. An adequate level of limits will allow the investor for reimbursement before the end of a contract. [Craig 1999; p.5-6]

\section{The forms of privatization}

The choice of the most suitable form of privatization is connected with a comprehensive decision-making process. Its result depends on prior aims of privatization. While making decision authorities should take into consideration such factors as: the range of maintained control, required investments, the current financial condition of an enterprise, the quality of management and know-how of an airport operator. According to A. Graham [2008; p. 25-32] five types of privatization can be distinguished:

- the issue of shares

- trade sale

- franchise contract

- project finance

- an administrative contract

The issue of shares. It is a process in which the state issues (all or part of) shares of a company on a stock exchange. A part of shares is reserved for buyback by the company's board. This process is supposed to contribute to stronger identification of workers with an organization aims. An obtained permission for the issue of shares is possible when the company fulfills given financial terms. Airports with week financial condition can not really opt for this solution. In the case of the issue of shares a new owner is usually in a role of a passive observer and they don't introduce any radical changes in the company's board, which still has an opportunity to control the way an airport operates. The board is obliged to prepare financial reports for shareholders and other investors. There is a risk that a great part of an organization potential will be concentrated on factors influencing only the share price.

Trade sale. It is a situation when a part or the whole airport is sold to a strategic partner or consortium of investors. The process usually takes place during an open public tender. In such case a tender commission has a chance to choose an entity which not only be a passive investor but also a strategic partner. In this case financial abilities, experience, organizational know-how and investor's technologies may constitute the priority factors.

Concession. It is a situation when a company specializing in operation of airports signs an agreement in which it obliges to implement investments and to manage the facilities 
through a specific period of time (usually $20-30$ years). Licensee assumes a full economic risk and responsibilities connected with investments and operation. The state can choose an investor in the process of a tender and break a contract when they stop fulfilling the earlier accepted obligations. The state has a bigger control over the facilities in the case of a full sale, and additionally it receives regular income with no risk, established as a fixed amount or percent from a profit.

Project finance. In this form of privatization an investor builds or transforms and then operates a given element of infrastructure (e.g. a terminal) through a fixed period. This type of agreement usually does not involve payment of deposit by an investor, but he is obliged to pay the costs of an investment. The most popular types of project finance are:

- BOT (build-operate-transfer): an investor builds the facilities, operates them through a given period of time and later hands over back to the state,

- BT (build-transfer): the facilities are transferred to the state immediately after being built

- BRT (build-rent-transfer): an investor builds the facilities, gives to the third entity for exploitation and after a given period of time transfers to the state.

- MPC (multiple prime contracts): tender commission choses a few main contractors and a manager

An administrative contract. It is a situation in which state entities retain airport's ownership as well as responsibilities for the development and investments. A contracting party operates an airport through a given period of time (usually 5-10 years). An administrative entity receives a honorarium from the state depending on financial results of an airport or transfers a fixed income percent. This option is politically easy to accept by public authorities as it does not involve a transfer of ownership. What is more it minimizes chances for accusations concerning a sale of national wealth. This model is well accepted by investors with a big aversion to risk, for whom the buyout of the whole airport is connected with big expenses and a potential risk.

\section{A risk connected with privatization}

The process of airports privatization connects with a risk for all the parties, taking part in it. Depending on the type of privatization these are: the state, a licensee and an investor. All parties assume risk in a different way and to a different degree. The participants of a privatization process have to be aware of threats which can appear while forming the plan of action. All the elements of risk should be identified and their influence and scale should be estimated. There is, however, a group of factors which implicates a risk for all parties. This is risk involving: [Craig 1999; p. 28]

- accuracy of forecasts concerning an increase of air traffic

- accuracy of estimated income and a cost of capital

- changeability of a economic and legislative surrounding.

\section{The factors of risk for investors}

A risk assumed by investors connects with many unknown points. Some of them result from uncertainty connected with income sufficient enough to cover all the investment and operational costs and allowing for repayment of capital costs. Other risk factors are technical parameters of infrastructure and any internal changes connected with airport operation (e.g. legislative and political environment, weather anomaly, catastrophes) [Craig 1999; p. 8] 


\section{The factors of risk for public authorities}

The factors of risk for public authorities are not always so obvious as in the case of risk taken by investors. One of the most common mistakes made by authorities is to rely to a great degree on technical and financial calculations offered by entities putting in a bid. In this case authorities can not be certain that they choose a way of airport development which is actually needed and economically rational. It is more difficult to compare offers in this situation. What is more, selection usually is based on a choice of an offer which predicts the highest benefits for a state budget. A risk here concerns the fact that a contract that may seem to be profitable, is based on predictions that are too optimistic. In this case there is a possibility that licensee will not be able to fulfill the given promises and after a few years will be forced to renegotiate contract terms under the threat of declaring bankrupt - the situation like this took place during privatization of Argentinian airports [Lipovich 2008; p. 8-15]

The next factor of risk for the state authorities is quality and adequacy of investments. Motivated by the will of generating as high profits as it is possible, an investor may have tendencies to neglect investments which are needed for increasing demand in air services. It may occur that in the final period of concession the airport infrastructure will be too obsolete and insufficient to meet demand. In extreme cases low flow capacity may contribute to slower economic development of a region. It concerns in particular communities which are geographically isolated and base their economy on tourism.

Moreover the tendency to monopolizing in the airports is another factor of risk. When the monopolistic company is managed by a private owner, there is a risk of imposing exorbitant charges, decreasing at the same time the air traffic. Consequently it would led to decreasing of external effects of a region. According to Vasigh, Fleming and Tacker [2008; p. 118], this kind of risk is little as far as regions with substitute for air services are concerned. In the case of too high airport fares passengers have a possibility to choose other means of transport such as railway, cars or further located airports.

Regional monopoly for airports brings the risk of a hostile takeover. The Slovakian Protection of Competition office in 1996 blocked the sale of majority package in Bratislava to TwoOne company, which operates the airport in Vienna. The distance between the two airports is only $40 \mathrm{~km}$ and more and more passengers going to Austria were landing in Bratislava. The reason for restraining privatization was a concern that a new owner will rise charges at the airport in Bratislava, transforming this airport into reserve one. [Czech
[Cusing Business News 2006]

\section{Privatization of airports in Poland}

Currently all the Polish airports have majority of state shares. So far only one privatization took place in Poland: in 2008 the company Meinl Airports International (today: Airports International) bought out from local self-government $49 \%$ of Bydgoszcz Ignacy Jan Paderewski Airport (IATA: BZG) shares. The privatization was justified by the necessity of airport infrastructure extension. The investments could have been funded partially from the EU finances, but local authorities did not have sufficient financial resources at that time to participate in these costs. Currently the airport has negative financial results and the only carrier (Ryanair) threats with closing of connections with Bydgoszcz in the case of not settling a $1.6 \mathrm{mln}$ debt, among others, for advertisement at its website [Aładowicz 2010]. 
Table 1. Ownership of Polish airports

\begin{tabular}{|c|c|c|c|c|c|}
\hline \multicolumn{2}{|r|}{ IATA } & Operator/Owner & Owner & Share & Private \\
\hline 1 & WAW & P.P. "Porty Lotnicze" & P.P. "Porty Lotnicze" & $100 \%$ & no \\
\hline \multirow[t]{4}{*}{2} & \multirow[t]{4}{*}{ KRK } & \multirow{4}{*}{ MPL im.J.P. II Kraków-Balice Sp. z o.o. } & P.P. "Porty Lotnicze" & $76,19 \%$ & no \\
\hline & & & Małopolskie voivodship & $22,73 \%$ & no \\
\hline & & & Commune of Kraków & $1,04 \%$ & no \\
\hline & & & Commune of Zabierzów & $0,04 \%$ & no \\
\hline \multirow[t]{4}{*}{3} & \multirow[t]{4}{*}{ KTW } & \multirow[t]{4}{*}{ Górnośląskie Towarzystwo Lotnicze S.A. } & Węglokoks S.A. & $40,29 \%$ & no \\
\hline & & & Śląskie voivodship & $38,15 \%$ & no \\
\hline & & & P.P."Porty Lotnicze" & $16,41 \%$ & no \\
\hline & & & Commune of Katowice & $4,63 \%$ & no \\
\hline \multirow[t]{3}{*}{4} & \multirow[t]{3}{*}{ GDN } & \multirow[t]{3}{*}{ Port Lotniczy Gdańsk Sp. z o.o. } & P.P. "Porty Lotnicze" & $36,59 \%$ & no \\
\hline & & & Pomorskie voivodship & $30,60 \%$ & no \\
\hline & & & Commune of Gdańsk & $31,36 \%$ & no \\
\hline \multirow[t]{3}{*}{5} & \multirow[t]{3}{*}{ WRO } & \multirow[t]{3}{*}{ Port Lotniczy Wrocław S.A. } & Commune of Wrocław & $47,82 \%$ & no \\
\hline & & & Dolnośląskie voivodship & $27,16 \%$ & no \\
\hline & & & P.P. "Porty Lotnicze" & $25,02 \%$ & no \\
\hline \multirow[t]{3}{*}{6} & \multirow[t]{3}{*}{$\mathrm{POZ}$} & \multirow[t]{3}{*}{ Port Lotniczy Poznań-Ławica Sp. z o.o. } & P.P. "Porty Lotnicze" & $49,89 \%$ & no \\
\hline & & & Commune of Poznań & $30,24 \%$ & no \\
\hline & & & Wielkopolskie voivodship & $19,87 \%$ & no \\
\hline 7 & RZE & P.P. "Porty Lotnicze" & P.P. "Porty Lotnicze" & $100 \%$ & no \\
\hline \multirow[t]{2}{*}{8} & \multirow[t]{2}{*}{ LCJ } & \multirow[t]{2}{*}{ Port Lotniczy Łódź Sp. z o.o. } & Commune of Łódź & 94,29 & no \\
\hline & & & Łódzkie voivodship & 5,7 & no \\
\hline \multirow[t]{4}{*}{9} & \multirow[t]{4}{*}{$S Z Z$} & \multirow[t]{4}{*}{ Port Lotniczy Szczecin-Goleniów Sp. z o.o. } & P.P. "Porty Lotnicze" & $58 \%$ & no \\
\hline & & & Commune of Szczecin & $34 \%$ & no \\
\hline & & & Commune of Goleniów & $5 \%$ & no \\
\hline & & & $\begin{array}{l}\text { Zachodnıopomorskıe } \\
\text { voivodship }\end{array}$ & $3 \%$ & no \\
\hline \multirow[t]{4}{*}{10} & \multirow[t]{4}{*}{$B Z G$} & \multirow[t]{4}{*}{ Port Lotniczy Bydgoszcz S.A. } & Airports International & $49 \%$ & yes \\
\hline & & & $\begin{array}{l}\text { Commune of Bydgoszcz } \\
\text { Kuiawsko-Pomorskie }\end{array}$ & $24 \%$ & no \\
\hline & & & voivodship & $18 \%$ & no \\
\hline & & & P.P. "Porty Lotnicze" & $8 \%$ & no \\
\hline 11 & IEG & P.P. "Porty Lotnicze" & P.P. "Porty Lotnicze" & $100 \%$ & no \\
\hline
\end{tabular}

Source: own compilation based on airports corporate data

The authorities of others airports do not intend to bring in the private capital. Many airports are in the process of infrastructure extension that is supposed to enlarge the capacity before the UEFA European Football Championship in 2012. The airports do not see a need to co-fund these investments with a private sector as they can use the EU funds and special subsidies from a state budget. The regional authorities want as well the airports to maintain the character of public utility as long as it will be possible. In this way local authorities can maintain a direct influence on the functioning if the airports as well as on shaping the strategies of air transport sector as a element of transport infrastructure development in a particular region.

\section{References}

1. Advani S. (1999), Passenger-Friendly Airports: Another Reason for Airport Privatization, Reason Policy Study, 
2. Aładowicz K. (2010), Ciąg dalszy afery lotniczej: Ryanair nie daruje, Gazeta Wyborcza Bydgoscz, 2010-04-28,

3. Craig V. (1999), Risk \& Due Diligence in Airport Privatization, ICAO,

4. Czech Business News (2006), Slovak Anti-Monopoly Office bans sale of Bratislava airport to Austria's TwoOne consortium, Czech Business News, September 12,

5. Dziennik Ustaw nr 118 poz. 561 (1996), Ustawa o komercjalizacji i prywatyzacji przedsiębiorstw państwowych, Art. 1,

6. Forsyth P., Gillen D., Knorr A., Mayer O., Niemeier H-M, Starkie D. (2004), The economic regulation of airports Recent developments in Australasia, NorthAmerica and Europe, Ashgate,

7. Freathy p. (2004), The commercialization of European airports: succesful strategies In a decade of turbulencje?, Journal of Air Transport Management, Elsevier,

8. Frost \& Sullivan (2006), Airport Privatisation, Frost \& Sullivan

9. Graham A. (2008), Managing Airports: An International Perspective, Elsevier,

10. Humphreys I. (1999), Privatisation and commercialisation: Changes in UK airport ownership patterns, Journal of Transport Geography

11. Lipovich G. A. (2008), The Privatization of Argentine Airports, Journal Air Transport Management 14, Elsevier,

12. Martín J.C. and Román C. (2001), An application of DEA to measure the efficiency of Spanish airports prior to privatization, Journal of Air Transport Management,Volume 7, Issue 3, May 2001, Pages 149-157

13. Müller, Ülkü and Živanović (2009), Privatization, restructuring and its effects on performance: A comparison between German and British airports, German Airport Performance, Paper No. 2., Date: 04/2009

14. Pitt M. (2001), Strategic direction in the airport business: enabling or disabling?, Facilities, Volume: 19 Issue: $3 / 4$

15. Parker, D. (1999), The performance of BAA before and after Privatization, Journal of Transport Economics and Policy, Vol. 33 No.2,

16. Poole R.W. Jr. (1994), Guidelines for Airport Privatization, How-To Guide No. 13, The Reason Foundation,

17. Silverleaf, A., Turgel, J. (1994), Deregulation and Privatisation in Transport, INTRA, Neuilly-sur-Seine

18. Suszyński C. (1999), Restrukturyzacja Przedsiębiorstw: Proces Zarządzania Zmianami, Polskie Wydawnictwo Ekonomiczne, Warszawa.

19. Polish Ministry of Tresury website http://prywatyzacja.msp.gov.pl/portal/pr/260/6861/Procedury_prywatyzacji_wstep.ht $\mathrm{ml}$

20. Szalbierz Z., Procesy Prywatyzacji Przedsiębiorstw Państwowych w Polsce, Prace Naukowe Instytutu Nauk Ekonomiczno-Społecznych Politechniki Wrocławskiej $\mathrm{Nr}$ 55 ,

21. Vasigh B., Fleming K.,Tacker T., (2008), Introduction to Air Transport Economics From Theory to Applications, Ashgate,

22. Vasigh B. and Haririan M. (2003), An empirical investigation of financial and operational efficiency of private versus public airports, Journal of Air Transportation, Vol. 8. No. 1.

23. Vogel H-A. (2006), Impact of privatisation on the financial and economic performance of European airports, The Aeronautical Journal, No. 2984,

24. Wells A.T., Young S.B. (2004) Airport Planning \& Management, McGraw-Hill Professional. 